\title{
NBEA wt Allele
}

National Cancer Institute

\section{Source}

National Cancer Institute. NBEA wt Allele. NCI Thesaurus. Code C143076.

Human NBEA wild-type allele is located in the vicinity of $13 q 13.3$ and is approximately 731 $\mathrm{kb}$ in length. This allele, which encodes neurobeachin protein, is involved the localization of protein kinase A. Mutations in or aberrant expression of the gene may be associated with autism, multiple myeloma and colorectal carcinoma. 